ISSN: $1896-4087$

DOI: http://dx.doi.org/10.21784/ZC.2017.014

BŁAŻEJ PRZYBYLSKI

Akademia Pedagogiki Specjalnej w Warszawie

\title{
Robert Pawlak, Przemiany edukacyjne w małym mieście, Wydawnictwo Akademii Pedagogiki Specjalnej, Warszawa 2016, ISBN 978-83-64953-44-6,
} ss. 343.

Funkcjonowanie systemu szkolnictwa należy do najczęściej poruszanych zagadnień pedagogicznych. Przedstawiciele różnych subdyscyplin nauk o edukacji systematycznie przyglądają się rozwiązaniom prawnym i instytucjonalnym, osiągnięciom w nauce, nierównościom edukacyjnym czy też realizacji konkretnych funkcji szkoły. Stosunkowo rzadko jednak możemy dotrzeć do całościowych monografii ukazujących funkcjonowanie szkolnictwa w konkretnym środowisku, uwzględniających wieloaspektowe i wielopłaszczyznowe odziaływanie edukacji. Próby opisania i wyjaśnienia przemian zachodzących w systemie edukacji i zdiagnozowania jej stanu na przykładzie jednej z polskich gmin podjął się socjolog edukacji, Robert Pawlak. Efektem jego wieloletnich badań jest książka zatytułowania „Przemiany edukacyjne w małym mieście”, która w 2016 roku ukazała się nakładem Wydawnictwa Akademii Pedagogiki Specjalnej w Warszawie.

Recenzowana publikacja liczy 343 strony; składa się z wprowadzenia, 14 rozdziałów oraz wniosków. Na ostatnich stronach zamieszczona jest mapa Wołomina oraz zdjęcia miasta, jego ulic, zabytkowych miejsc i placówek publicznych, w tym szkół. Standardowa struktura książki obejmuje część teoretyczną i empiryczną. 
Błażej Przybylski - Robert Pawlak, „Przemiany edukacyjne...” [rec.]

Pierwsze dwa rozdziały mają charakter teoretyczny. Nie są obszerne, liczą ledwie 40 stron. Autor dokonuje na nich przeglądu badań poświęconych społecznościom lokalnym oraz prowadzi przejrzystą narrację na temat skomplikowanych i wieloaspektowych relacji między globalizacją a edukacją. Związek ten nie może dziwić, gdyż:

(...) instytucje edukacji masowej zadomowiły się na dobre w krajobrazie współczesnych społeczeństw i stały się elementem życia każdego człowieka. Ich funkcjonowanie, i co za tym idzie, wpływ na jednostki uwarunkowane są szerszymi procesami społecznymi i kulturowymi. Edukacja jest w tym procesie zarówno przedmiotem oddziaływań czynników globalnych, jak i sama stymuluje ład społeczny poprzez efekty swojej pracy ${ }^{1}$.

Robert Pawlak w sposób zwięzły odnosi się do współcześnie kluczowych zagadnień i problemów nurtujących nie tylko polski system edukacyjny. Sporo uwagi poświęca problemom młodzieży, która przechodząc przez kolejne szczeble edukacji, wreszcie zdobywając upragnione wyższe wykształcenie, nie potrafi odnaleźć się na rynku pracy. Autor, choć opisanej klasy nie nazywa wprost prekariatem, kreśli portret właśnie tej kategorii społecznej. Powstawanie odrębnej grupy socjoekonomicznej wydaje się zjawiskiem typowym dla krajów rozwijających się, bowiem: „miliony ludzi w zamożnych i wschodzących gospodarkach rynkowych weszły w skład prekariatu"2.

$\mathrm{W}$ innym miejscu porusza zagadnienia związane z procesami neoliberalnymi, jak problem urynkowienia i umasowienia edukacji czy też dominującej szkolnej kultury testowania. W polskiej literaturze pedagogicznej powyższe zagadnienia są dość dobrze rozpoznane. Na powyższe zjawiska zwraca uwagę liczne grono badaczy, chociażby Przemysław Sadura, autor raportu z badań nad nierównościami edukacyjnymi, podkreślał, że „dominującym w Polsce kierunkiem myślenia o systemie oświatowym jest naiwny produktywizm, posługujący się argumentami zaczerpniętymi z języka racjonalności ekonomiczs. 51.

${ }^{1}$ P. Mikiewicz, Socjologia edukacji. Teorie, koncepcje, pojęcia, Warszawa 2016,

2 G. Standing, Prekariat. Nowa niebezpieczna klasa, Warszawa 2014, s. 42. 
nej"3. W swojej książce Robert Pawlak omawiane zjawiska traktuje zwięźle i rzeczowo; stanowią one wstęp do prezentacji wyników badań własnych.

W trzecim rozdziale zawarte są metodologiczne założenia badań własnych; w następnych kilkunastu rozdziałach - wnikliwa i gruntowna analiza systemu edukacji $\mathrm{w}$ podwarszawskiej gminie Wołomin. Autor powraca do wołomińskiego środowiska, w którym już w latach 90. przeprowadził pierwsze badania. Recenzowana książka jest drugą pracą Roberta Pawlaka, ukazującą lokalne przemiany w systemie szkolnictwa w gminie Wołomin.

W rozdziale metodologicznym zaprezentowano opis najważniejszych założeń badawczych. Badania miały charakter monograficzny. Pytania badawcze, na które Autor poszukiwał odpowiedzi, obejmowały główne kierunki polityki oświatowej i najważniejsze problemy edukacyjne: urynkowienie oświaty, nierówności edukacyjne, działalność szkół i organizacji pozarządowych na rzecz umacniania spójności społecznej, rola szkoły wyższej w społeczności lokalnej. Autor dokonał triangulacji metod badawczych. Na słowa uznania zasługuje realizacja procesu badawczego, $\mathrm{w}$ tym przede wszystkim zakres materiałów, które zostały włączone do analizy. Pracownik Akademii Pedagogiki Specjalnej im. Marii Grzegorzewskiej w Warszawie zanalizował kilkanaście rodzajów dokumentów urzędowych, treści artykułów prasowych, statystyki publikowane przez liczne instytucje publiczne oraz przeprowadził ponad sto indywidualnych wywiadów pogłębionych z przedstawicielami władz, nauczycielami i zwykłymi mieszkańcami gminy. Dzięki tak obszernemu materiałowi uzyskał kompletny obraz procesów zachodzących w Wołominie, dotyczących zwłaszcza obszaru edukacji. $\mathrm{W}$ jednym $\mathrm{z}$ bardziej popularnych podręczników do metodologii badań społecznych Janusz Sztumski wskazywał, że „metoda monograficzna jest jedną z metod najwcześniej stosowaną w socjolo-

\footnotetext{
${ }^{3}$ P. Sadura, Szkoła i nierówności społeczne. Diagnoza zjawiska i propozycja progresywnej polityki edukacyjnej w Polsce, Warszawa 2012 , s. 11.
} 
Błażej Przybylski - Robert Pawlak, „Przemiany edukacyjne...” [rec.]

gii empirycznej"4. Przyglądając się warsztatowi badawczemu, można odczuwać pewien niedosyt z powodu braku krytycznego i pogłębionego spojrzenia na samą metodę monograficzną, która w Polsce cieszy się bardzo długą tradycją, by wspomnieć choćby prace Franciszka Bujaka ${ }^{5}$, Katarzyny Dudy-Dziewierz ${ }^{6}$ czy Józefa Chałasińskiego ${ }^{7}$. Sądzę, że zwłaszcza dla studentów zapoznających się z tą książką szersza prezentacja ram teoretycznych i istoty monografii naukowej stanowiłaby cenne uzupełnienie.

Na początku części empirycznej poznajemy bliżej gminę Wołomin, jej historię i specyfikę wynikającą z czynników geograficznych. Jest to gmina uznawana za „sypialnię wielkiego miasta”, które „wysysa potencjał Wołomina”. Położenie miasta, jak zauważa Robert Pawlak, „jest centralnym odniesieniem dla władz gminy i jej mieszkańców, a Warszawa najważniejszym rynkiem pracy. Stolica zajmuje pozycję «centralną» w regionie wobec "peryferii». Jej bliskość tylko częściowo rozwiązuje problemy Wołomina". Autor wyczerpująco kreśli społeczny portret Wołomina, dając czytelnikom pełen obraz społeczno-demograficzny miasta. Przedstawia liczne dane statystyczne z uwzględnieniem wielu zmiennych, jak np. płeć, religijność, uczestnictwo w praktykach religijnych, zaangażowanie polityczne, preferencje partyjne, dochód, poziom wykształcenia i bezrobocia czy przestępczość. Zapewne dotychczasowa wiedza o Wołominie większości czytelników nie wykraczała poza medialne doniesienia związane $\mathrm{z}$ funkcjonowaniem tzw. gangu wołomińskiego. Tymczasem z lektury nie tylko dowiadujemy się o tym, że w oczach mieszkańców Wołomin jawi się jako miejsce przyjazne i bezpieczne, poznajemy też cały kontekst społeczny, ekonomiczny oraz kulturowy gminy leżącej nieopodal stolicy. Z podobnymi problemami borykają się zapewne również inne mniejsze

\footnotetext{
4 J. Sztumski, Wstęp do metod i technik badań społecznych, Katowice 2010, s. 114.

${ }^{5}$ Np. F. Bujak, Żmiąca. Wieś powiatu limanowskiego. Stosunki gospodarcze i społeczne, Kraków 1903.

${ }^{6}$ Np. K. Duda-Dziewierz, Wieś małopolska a emigracja amerykańska: studium wsi Babica powiatu rzeszowskiego, Warszawa 1938.

7 Np. J. Chałasiński, Antagonizm polsko-niemiecki w osadzie fabrycznej Kopalnia, Warszawa 1935.
} 
miasta i miasteczka położone w okolicach wielkich aglomeracji miejskich.

Autor poświęca dużo miejsca omówieniu politycznych wyborów mieszkańców, tradycyjnie popierających środowiska konserwatywne. Prezentuje wyniki kolejnych wyborów i referendów. W mieście wyraźnie dominuje nad pozostałymi siłami politycznymi Prawo i Sprawiedliwość, co też wskazuje na polityczną odmienność Wołomina od Warszawy, w której przeważają zwolennicy środowisk liberalnych i lewicowych. Interesująco zostały opisane samorządowe potyczki o fotel prezydenta miasta, lokalna elita władzy oraz najważniejsze spory toczone w gminie. Powstaje wrażenie, że są one bezpośrednim odzwierciedleniem konfliktów ogólnopolskich, powszechnie znanych z przekazów medialnych. Konflikty samorządowców z Wołomina dotyczą przede wszystkim pamięci historycznej, obsady stanowisk oraz lokalizacji inwestycji. Za najważniejszy spór, szeroko opisywany w lokalnych gazetach, należy uznać kwestie budowy pomnika ofiar katastrofy lotniczej w Smoleńsku. Autor, przytaczając wypowiedzi mieszkańców i władz oraz fragmenty doniesień medialnych, rekonstruuje konflikt wokół postawienia w centralnym miejscu Wołomina popiersia Lecha Kaczyńskiego. Jak w kalejdoskopie widać, że spory partyjne przenoszą się również na poziom mikro, gdzie stają główną osią podziałów w środowiskach lokalnych.

Zdecydowanie najobszerniejsza część pracy dotyczy już bezpośrednio edukacji w gminie Wołomin. Autor rozpoczyna opis przypadku od charakterystyki wołomińskiego systemu szkolnictwa z uwzględnieniem wszystkich etapów edukacji formalnej. Dalej dokonuje przeglądu i charakterystyki zmian demograficznych zachodzących w gminie Wołomin. Autor konkluduje, że mimo iż - zdaniem władz procesy demograficzne są brane pod uwagę przy projektowaniu budżetu i ustalaniu strategii edukacyjnej, przewidywania nie zawsze okazują się celne. Jego analizy potwierdzają tezy sformułowane niegdyś, m.in. przez Mikołaja Kozakiewicza, że czynniki demograficzne mogą przyczyniać się do różnicowania szans edukacyjnych młodzieży. 
Błażej Przybylski - Robert Pawlak, „Przemiany edukacyjne...” [rec.]

Znamienity socjolog edukacji wskazał na szereg czynników stanowiących bariery w procesach kształcenia, oprócz demograficznych wyróżnił on: ekonomiczne, przestrzenne i regionalne, psychologiczne, ideologiczne, kulturowe, płci oraz szkolno-oświatowe ${ }^{8}$. W pracy autorstwa Rafała Pawlaka znajdziemy szersze opisy konkretnych przeszkód, jakie napotyka społeczność małego miasta na swojej drodze edukacyjnej.

Dokładnie widzimy, że w jednej gminie niemalże w sąsiedztwie funkcjonują zupełnie odmienne światy szkolne. W samym centrum Wołomina klasy są przeludnione, lekcje odbywają się w trybie dwuzmianowym, podczas gdy niedaleko poza miastem, w sąsiednich wsiach, placówki są gorzej wyposażone, zaś klasy święcą pustkami; uczęszcza do nich po kilkoro dzieci. Problematyka ta w polskiej literaturze socjologicznej i pedagogicznej została dobrze opisana. Mirosław Józef Szymański podkreśla, że:

(...) nawet pobieżna obserwacja przebiegu procesu kształcenia i wychowania w szkolnictwie polskim pozwalała i nadal pozwala dostrzec, że warunki pracy w szkołach miejskich, stosowane formy pracy, uzyskiwane efekty bardzo często różnią się od tych, które mają szkoły na wsi. Nie mniej widoczne różnice jawią się w grupie szkół funkcjonujących na terenie miasta9 ${ }^{9}$

Poza tym na codzienną szkolną rzeczywistość składają się także patologie społeczne i problemy wychowawcze, nadużywanie środków psychoaktywnych, czy brak jakiejkolwiek kontroli nad czasem wolnym dzieci i młodzieży, zarówno ze strony szkoły, jak i rodziców. Po lekturze recenzowanej książki problem współpracy między szkołą a rodzicami wydaje się jak najbardziej aktualny i potwierdzający tylko wcześniejsze przypuszczenia pedagogów.

Za partnerstwem rodziny i szkoły przemawiają także liczne badania, praktyka codzienna szkół, które muszą się zmagać z nowymi wyzwaniami, wielokultu254.

8 M. Kozakiewicz, Bariery awansu poprzez wykształcenie, Warszawa 1973, s. 49-

${ }_{9}^{9}$ M. J. Szymański, Studia i szkice z Socjologii Edukacji, Warszawa, 2015, s. 134. 
rowością, nowymi nierównościami społecznymi, wysokimi aspiracjami rodziców i dzieci, ale także absencją szkolną, niepowodzeniami szkolnymi etc. ${ }^{10}$.

Celem współpracy pomiędzy środowiskiem rodzinnym i szkolnym ma być jak najwszechstronniejszy rozwój dziecka, co w efekcie przenosić się będzie również na budowanie kapitału ludzkiego i społecznego gminy. Problemy socjalne oraz opiekuńczo-wychowawcze stanowią poważne wyzwanie dla władz politycznych i oświatowych.

W publikacji mamy możliwość zapoznania się z licznymi problemami, które dotyczą nie tylko edukacji, ale także spraw socjalnych w gminie Wołomin. Są znane od lat 90., a jednak wielu z tych bolączek nie udało się do dziś wyeliminować. Autor wskazuje przede wszystkim na wysokie koszty utrzymania szkół, problemy z dostępem do edukacji dzieci ze środowisk wiejskich czy trudności adaptacyjne nauczycieli do zmieniających się warunków pracy. Kwestie te od dawna są diagnozowane i interpretowane przez liczne grona naukowców zajmujących się problematyką edukacji. Równocześnie Autor śledził efekty reform w systemie edukacyjnym. Na przykładzie jednej gminy możemy zaobserwować je w perspektywie mikro.

W silnie scentralizowanym systemie szkolnym, jakim jest niewątpliwie polskie szkolnictwo od początku PRL po dzień dzisiejszy (z krótką przerwą wolności w latach 1989-1993) odgórne wprowadzanie reform edukacyjnych opierało się na aktach przymusu prawnego i manipulacji administracji rządowej, skazując je tym samym na niepowodzenie. Silny opór wobec nich generowany był przez wiele podmiotów stricte oświatowych, ale i pozaoświatowych, gdyż w wyniku przemian demokratycznych włączają się w ten proces także organizacje pozarządowe, $\mathrm{w}$ okresie totalitaryzmu zaś przeciwdziałała im opozycja11.

Badania zostały zrealizowane w czasie, kiedy odgórnie obniżano obowiązkowy wiek szkolny do lat sześciu. Opinie rozmówców, w tym nauczycieli, były w większości sceptyczne co do pomysłu koalicji PO-

10 B. Smolińska-Theiss, Dzieciństwo jako status społeczny. Edukacyjne przywileje dzieci klasy średniej, Warszawa 2014, s. 102.

${ }^{11}$ R. Nowakowska-Siuta, B. Śliwerski, Racjonalność procesu kształcenia. Studium z polityki oświatowej i pedagogiki porównawczej, Kraków 2015, s. 202. 
Błażej Przybylski - Robert Pawlak, „Przemiany edukacyjne...” [rec.]

PSL. W społeczeństwie polskim w kontrze do pomysłów rządzących pojawił się silny ruch oporu nawołujący do ratowania sześciolatków przed obowiązkiem szkolnym. Obecnie doświadczamy kolejnych zmian w systemie edukacyjnym, które być może zainspirują Autora do powtórnych odwiedzin w wołomińskich szkołach i tym razem poznania oczekiwań i obaw przed kolejną reformą.

Przyglądając się młodzieży z Wołomina, Autor potwierdza rozważania teoretyków dotyczące braku perspektyw młodzieży. Lektura publikacji utwierdza w przekonaniu, że Zygmunt Bauman trafnie nazywał współczesne młode pokolenie „pokoleniem straconym”. Jak zauważał wybitny polski socjolog:

(...) to prawda, że każde pokolenie ma swoich wyrzutków... W każdym pokoleniu są ludzie skazani na status wyrzutka, gdyż „zmiana pokoleniowa” powoduje niebagatelne zmiany w warunkach życia i jego wymogach, w wyniku których rzeczywistość, odbiega od wcześniej ukształtowanych oczekiwań, a umiejętności, które wcześniej ceniono i rozwijano, tracą na wartości. (...) Jednakże nieczęsto zdarza się, że los wyrzutka przypada całemu pokoleniu. A być może tego właśnie jesteśmy świadkami obecnie ${ }^{12}$.

Czytając rozważania dotyczące młodzieży wołomińskiej pozbawieni jesteśmy złudzeń: większość młodych ludzi będzie musiało w przyszłości szukać pracy poza miejscem zamieszkania albo podejmować się pracy, która nie będzie spełniać ich aspiracji i odpowiadać zdobytemu wykształceniu formalnemu. Robert Pawlak kreśli mało optymistyczną wizję przed młodymi ludźmi z Wołomina. Posiłkując się wypowiedziami nauczycieli oraz rodziców, podkreśla, że większość uczniów najprawdopodobniej zostanie zmuszona do opuszczenia gminy na stałe lub przynajmniej do pracy w Warszawie, a co za tym idzie traktowania rodzinnego miasta jako sypialni. Już dziś znaczna część nastolatków uczy się poza terenem powiatu wołomińskiego, dojeżdża do szkół do Warszawy, która kusi większymi możliwościami i „lepszymi”, bardziej prestiżowymi szkołami. Narracje te dobrze wpisują się we współczesne podejście do edukacji i wykształcenia. Dziś

12 Z. Bauman, O edukacji. Rozmowy z Riccardo Mazzeo, Wrocław 2012, s. 53. 
bowiem szkoły coraz częściej traktowane są jako instytucje, które dają tylko uwierzytelnienie w oczach przyszłych pracodawców. Dyplomy zaś stają się listami uwierzytelniającymi nasze kompetencje oraz umiejętności. Uczniowie przekonani są o konieczności posiadania jak najlepszego dyplomu, nie do końca jednak wierzą w przydatność wiedzy zdobytej w szkole w dorosłym życiu.

Mimo że w Wołominie istnieje wyższa uczelnia (autor opisuje jej początki i obecne realia funkcjonowania), nie cieszy się ona znaczącym prestiżem wśród społeczności lokalnej. Zbigniew Kwieciński, opisując wzrost znaczenia wykształcenia formalnego, wskazywał, że ważnym:

elementem napędzania tej koniunktury jest zaistnienie lokalnej oferty, a zatem fizyczna dostępność uczelni w wygodnym czasie, niekolidującym w pewnej mierze z czasem pracy, oraz opinia o względnej łatwości takich studiów w porównaniu ze studiami stacjonarnymi. Towarzyszy temu formalne „odróżnicowanie" wartości dyplomów ${ }^{13}$.

W obliczu zmian demograficznych, instytucjonalnych i ekonomicznych przyszłość wołomińskiej szkoły wyższej stoi jednak pod dużym znakiem zapytania. Potencjalni studenci wolą wybierać szkoły o wyższym prestiżu i publiczne bezpłatne. Aktualnie sporą część społeczności studenckiej stanowią obcokrajowcy. Na marginesie, Autor zauważa, że problemem jest wrogość mieszkańców Wołomina wobec obcokrajowców, szczególnie tych o innym kolorze skóry. Co więcej, władze Uczelni w celu zapewnienia tym osobom bezpieczeństwa zdecydowały się na zapewnienie im zakwaterowania w Warszawie. Tej lokalnej ciekawostce Autor nie poświęca wiele uwagi, a z pewnością zasługuje ona na bardziej wnikliwą refleksję. Zygmunt Bauman zauważał, że:

(...) potrzeba bezustannego i codziennego doskonalenia, uczenia i praktykowania sztuki współżycia z obcymi i ich odmiennością jest nieuchronna jeszcze z innego powodu: bez względu na to, jak bardzo rządy poszczególnych państw s. 93.

13 Z. Kwieciński, Pedagogie postu. Preteksty - konteksty - podteksty, Kraków 2012, 
Błażej Przybylski - Robert Pawlak, „Przemiany edukacyjne...” [rec.]

usiłują powstrzymać napływ imigrantów, nie przestaną oni stukać do bram tych państw, a bram tych raczej nie da się zaryglować"14.

Jak widać na przykładzie Wołomina, sztuka współżycia z innymi w tym mieście nie została jeszcze przyswojona ani opanowana. Niechęć do studentów z innych krajów każe zastanowić się zarówno nad stanem polskiego społeczeństwa, jak i dotychczasowego modelu edukacji; edukacji, która ma przede wszystkim uczyć do życia w różnorodnym i wielokulturowym społeczeństwie.

W kontekście obecnych debat na temat przyjmowania uchodźców czy w ogóle stosunku Polaków do inności publikacja Rafała Pawlaka rzuca światło na „polską gościnność”. Zważywszy na charakter miasta leżącego w pobliżu coraz bardziej wielokulturowej metropolii, problem związany ze stosunkiem do obcokrajowców uwidacznia też społeczne bariery w rozwoju miasta. Globalizacja, o której Autor pisze w części pierwszej, oznacza przecież nie tylko strumień finansów płynący z Zachodu, ale też migracje osób pochodzących z innych kręgów kulturowych, a w konsekwencji również nowe wyzwania stojące przed społeczeństwem. Szersze spojrzenie na mieszkańców Wołomina, w tym szczególnie na młodzież, jej światopoglądy oraz postawy wobec „innych”, stanowiłoby ciekawe uzupełnienie wizerunku miasta. Znaczna część młodzieży dryfuje dziś bowiem w kierunku ruchów skrajnie prawicowych, antydemokratycznych, ksenofobicznych i nacjonalistycznych. Wśród młodych mieszkańców Wołomina, niechętnych studentom z innych państw, zapewne podobne tendencje są widoczne.

Recenzowana książka z pewnością stanowi ważne źródło informacji na temat przemian w edukacji, jej problemów i wyzwań, którym winna sprostać w najbliższych latach. Napisana językiem czytelnym i przystępnym, może być adresowana nie tylko do środowisk naukowych, ale też do czytelników zainteresowanych szkolnictwem w omawianej i wielu podobnych gminach. Autor rzetelnie i kompleksowo portretuje dość specyficzne środowisko lokalne, pokazując, niestety,

14 Z. Bauman, 0 edukacji.., op. cit., s. 11. 
głównie bariery, zaś w mniejszym tylko stopniu szanse rozwojowe otwierające się przed gminą. Szanse, które - jak zauważa autor, przyglądając się Wołominowi od niemal 20 lat - nie zostały dotychczas wykorzystane. Monografia ta właśnie ze względu na swoją aktualność może stanowić ważne źródło historyczne, służące za wskazówkę lokalnym działaczom i decydentom.

\section{Bibliografia:}

Bauman Z., O edukacji. Rozmowy z Riccardo Mazzeo, Wydawnictwo Naukowe Dolnośląskiej Szkoły Wyższej, Wrocław 2012.

Bujak F., Żmiq̨ca. Wieś powiatu limanowskiego. Stosunki gospodarcze i społeczne, Nakład Gebethner i Spółka w Drukarni Uniwersytetu Jagiellońskiego pod zarządem Józefa Filipowskiego, Kraków 1903.

Chałasiński J., Antagonizm polsko-niemiecki w osadzie fabrycznej Kopalnia, Sp. Akc. Dom Książki Polskiej, Warszawa 1935.

Duda-Dziewierz K., Wieś małopolska a emigracja amerykańska: studium wsi Babica powiatu rzeszowskiego, Polski Instytut Socjologiczny, Warszawa 1938.

Kozakiewicz M., Bariery awansu poprzez wykształcenie, IW CRZZ, Warszawa 1973.

Kwieciński Z., Pedagogie postu. Preteksty - konteksty - podteksty, Oficyna Wydawnicza „Impuls”, Kraków 2012.

Mikiewicz P., Socjologia edukacji. Teorie, koncepcje, pojęcia, PWN, Warszawa 2016.

Nowakowska-Siuta R., Śliwerski B., Racjonalność procesu kształcenia. Studium z polityki oświatowej i pedagogiki porównawczej, Oficyna Wydawnicza „Impuls”, Kraków 2015.

Sadura P., Szkoła i nierówności społeczne. Diagnoza zjawiska i propozycja progresywnej polityki edukacyjnej w Polsce, Amicus Europae, Warszawa 2012.

Smolińska-Theiss B., Dzieciństwo jako status społeczny. Edukacyjne przywileje dzieci klasy średniej, Wydawnictwo Akademii Pedagogiki Specjalnej, Warszawa 2014.

Standing G., Prekariat. Nowa niebezpieczna klasa, PWN, Warszawa 2014. 
Błażej Przybylski - Robert Pawlak, „Przemiany edukacyjne...” [rec.]

Sztumski J., Wstęp do metod i technik badań społecznych, „Śląsk” Sp. z o.o Wydawnictwo Naukowe, Katowice 2010.

Szymański M. J., Studia i szkice z Socjologii Edukacji, Wydawnictwo Akademii Pedagogiki Specjalnej, Warszawa, 2015. 